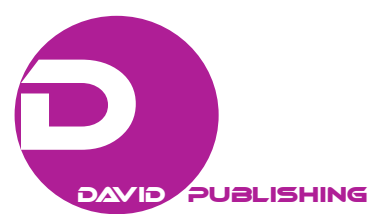

\title{
Fight Against Poverty From the Islamic Point of View: The Wealth Distribution and Share
}

\author{
Ali Kuzudisli \\ Gumushane University, Gumushane, Turkey
}

\begin{abstract}
Today, poverty is one of the most important problems in the world. This is not only the problem of poor people living in specific regions but also the problem of all people in general. Poverty is expected to decrease as the welfare level increases. The World Bank predicts that extreme poverty will disappear until 2030 but mentions significant hesitations in achieving this objective. Even though extreme poverty will have actually disappeared in 2030 , the deep gap between the richest $20 \%$ and the poorest $20 \%$ will continue to maintain its presence. There are many reasons for poverty arising from individuals such as illiteracy, inexperience, and laziness. However, there are many reasons for poverty beyond the individual such as the management of the capital by a small group of people. While the capital continuously increases under the control of a narrow group, poor community deprived of increasing welfare benefits from it slightly and too late. In this case, the solutions that individuals striving to live below the poverty line can find on their own in order to keep alive remain quite limited. Islam has a shorter term solution for welfare share: Transferring a small amount of high-income group's wealth to the low-income group. Through this worship called zakat, it is aimed to rid poor people of desperation. It is not theoretically impossible to develop a method to reduce income inequality by taking the worship of zakat as a model.
\end{abstract}

Keywords: poverty, Islam, zakat, welfare sharing, wealth distribution, the Islamic perspective, the Islamic point of view

\section{Introduction}

The World Bank set two targets in 2013 for "The world without poverty": The elimination of extreme poverty and ensuring the welfare share in 2030. According to the data presented, income per capita has increased in the last 25 years around the world, on the contrary, extreme poverty has decreased from 1.90 billion to 720 million. Despite these pleasing developments, the number of extremely poor people in the world is still high and concentrated in specific regions such as the south of the African continent and South Asia (Cruz, Foster, Quillin, \& Schellekens, 2015).

The solution suggested for the elimination of extreme poverty ensures income per capita to increase a bit more. According to the assumption, poverty will decrease as income per capita increases and will eventually disappear. Besides, difficulties such as wars, forced migrations, and natural disasters pose significant risks in achieving the 2030 target. It is required to have a long time and wait for those with high welfare level to become richer for the elimination of extreme poverty even if everything takes its natural course. Since while

Ali Kuzudisli, associate prof., Main Islamic Sciences, Gumushane University, Gumushane, Turkey.

Correspondence concerning this article should be addressed to Ali Kuzudisli, Gumushane University, Baglarbasi Mah., Gumushane, Turkey. 
income per capita increases, those with high-income levels get the biggest share from this development. Apparently, people whose daily income is not even a dollar have to wait for the further increase in incomes of those with high income to be able to keep alive. Such as, a rich businessman turns his back to a hungry beggar who begs for money and says: "Pray for me, may my wealth be doubled, and then you will have two dollars a day".

The fact that states aim at a steady growth can be seen as normal, however, equal distribution of income between households should be considered important at least as much as the first one. The fact that poverty becomes widespread is a negative situation not only for poor people but also for everyone. Since in today's world, none of the problems with a greater extent remains at the local level, but they affect the whole world. In a world where people are constantly harassed to spend money, problems caused by people with a low-income level become evident in many forms at the local and global scale.

The status of the poorest $10 \%$ constitutes the portion of the poverty problem that should be resolved first and most quickly. In the present conditions, these people almost have no chance to get rid of severe living conditions they have through their own means. Therefore, they have the characteristics of being a potential source for all kinds of criminal and terrorist organizations.

Islam has considered inequality in the income distribution as a big problem since the first period of its emergence and has taken some measures through direct and indirect ways to overcome it. Firstly, it is necessary to lay emphasis on some basic concepts at the background to be able to understand what Islam foresees about fighting against poverty and inequality in income distribution.

\section{Background: Justice, Property, Wealth, Food, and After-life}

Justice (al- 'adl in Arabic) which is one of the most important concepts of Islam is derived from the same root $a l$ - $a d l$, which is one of the names of Allah. Justice is often used in the meanings of "order, equilibrium, equality, fair judge, finding the right way, honesty, and objectivity" in the Quran. The fact that harmony, coherence, and aesthetic appearance in the physiological structure of the human are expressed with the concept of justice in the Quran is quite remarkable (Quran: 82/7). In the interpretation of "a wasat (just) ummah" (Quran: 2/143) which is used as characteristics of the Islamic community in the Quran, the word al-wasat is used in the meaning of "justice". The Quran likens a person who lacks the attributes of justice to a dumb, incapable, and useless slave (Quran: 16/76). Human should be fair (Quran: 5/8) and speak fairly (Quran: 6/152) to be able to gain the virtue of taqwa which is the highest measure of value in the eye of Allah. Essentially, honesty ( $a l$-sidq) and justice ( $a l$ - ' $a d l$ ) are the attributes of divine words (Quran 6/115; Cagrici, 1988).

As to the issue of property, the true owner of the property is Allah according to Islam. Human has been granted authority to have something and use it for a limited time (Quran: 57/7). A human who works appropriately to the conditions can get wealth by the will of Allah. What important in the presence of Allah is not how much wealth the human has but whether he/she gets his/her wealth in a legitimate way and what he/she has done with that wealth. This can be elaborated a little more.

Generally, a person can get a property by one of two ways. The first way is to work and gain. Working and gaining also have various laws to get the property. Even though a person has exerted great effort through illegal ways, his/her gain is not legitimate. For instance, a person cannot cultivate the garden of someone else without permission. Gaining property through production also has many laws. The gain of a person must remain within its legal framework to be haläl. Illegal profit is forbidden by the Quran (4/29). The second way to get property is inheritance or grant; gaining property through this way also has many laws. 
Islam does not interfere with personal property as long as it is within the legal framework. However, Islam turns Muslims' face towards the eternal blessings of heaven on all occasions to ensure they avoid passion for goods (Quran: 28/60). Quran praises a rich person only if he/she is a giver. Apart from this, no person is accepted as valuable because of his/her wealth. Accordingly, what making wealth valuable is that it is spent for the decrease in evil and poverty or for the advancement of goodness and sharing, that is "for the way of Allah".

Islam disapproves the fact that a person lives off someone else for human dignity without a valid excuse. According to Islam, Allah has created the sustenance of every person, and he/she must make an effort to earn a livelihood (Quran: 35/12).

The aforementioned "sustenance" concept is one of the remarkable concepts of the Quran. Allah gives the sustenance of every creature, big or small (Quran: 11/6). The Holy Quran has severely criticized Bedouin Arabs' custom to kill their daughters by burying them alive for the fear of sustenance (Quran: 6/151) and has banned people from stealing sustenance of others (Quran: 20/131). People should be honest while working; they should not think that they would make a loss because of their honesty since Allah provides food for good servants from where they cannot expect (Quran: 65/3).

The main motivation of fulfilling the obligations is after-life in Islam. Therefore, the Holy Quran tries to create the awareness of after-life in Muslims. According to Islam, the real life starts after this life ends. The temporal blessings in the world are just for being tested (Quran: 57/20; 67/2). People are consistently tested by their goods, children, and other things they have throughout their lives. They should resist to all difficulties they face with "the way of Allah" and should be patient for the realization of what Allah has promised for the after-life. The stories of the prophets expressed in the Quran usually address this theme and thereby encourage people to do the right behavior. A person who has performed good deeds by protecting his mind and heart deserves heaven as a virtuous person who has successfully passed the exam.

Heaven is the home of eternal peace and confidence with unlimited unique pleasures contrary to pain, sadness, and chaos of this world (Quran: 55/48). Hell which is located across the Heaven is a place with frightful torments. The Quran has threatened those people who regard themselves irresponsible to Allah, therefore, irresponsibly perform all kinds of evil, with the hell.

The Quran is aware of people's passion for wealth and prosperity. The Quran often reminds people about after-life and emphasizes that the blessings of heaven are superior and eternal since this passion is strong enough to misguide people. However, the Quran has not set a limit for gaining goods on condition that this should be performed through halal ways and what necessary should be done. Although the Quran does not praise people's effort to save great fortunes day and night in any verse, this is not prohibited in the Quran. What is persistently emphasized about goods and money by the Quran is the fact that wealth should not become a power that circles within a narrow environment. The clear warning about this is expressed in the Quran as follows: "...so that it will not be a perpetual distribution among the rich from among you..." (Quran: 59/7). This general rule is included in a verse that describes how prizes obtained from the conquered territories should be shared out.

In such a basis summarized briefly, the Holy Quran has ordered and recommended Muslims to share some portion of their fortune with poor people, al-sadaqah, alms-charity, some penances, sacrifices, foundation, etc. including zakat which is an obligatory worship can be included in the institutions set by Islam concerning goods sharing. Here it will solely focus on zakat institution which means that a rich Muslim shares two and a 
half percent of his wealth on average with poor people. As it is seen below, this order of the Quran has interesting features to mitigate the harmful effects of income inequality.

\section{Zakat}

Zakat can be defined as "granting some amount of property to poor Muslims after a certain period elapsed for the sake of Allah" (al-Mawsili, 1937, p. 99), al-sadaqah is a worship encouraged by Islam from the beginning and has a freer form than zakat (Islahi, 1993). Zakat, according to the general acceptance, was ordered in the second year of the hijra to Medina (Erkal, 2013). When zakat was ordered, officials who were in charge of collecting zakat were sent to the cities where Muslims lived, and some portion of rich people's property was taken in accordance with the conditions and given to poor people. At first, zakat was a symbol of being a Muslim such as performing prayer. After the death of the Prophet, when some tribes did not want to pay zakat, the first Caliph Abu Bakr considered this as a rebellion against the state administration and sent the army to them. In subsequent years, the third Caliph Osman excluded zakat's collection from being a duty of the state. Thereafter, religious people gave their zakat of their own accord.

\section{Zakat and Tax}

In today's society, there have been some comparisons between zakat and tax (Eskicioglu, 1989). In these comparisons, the most obvious difference observed between them is that tax is collected from the profit and zakat is collected from the wealth. Accordingly, a Muslim, who has gold or cash money but does not make use of them in trade, does not have to give any tax but is obliged to give two and a half percent of his wealth as zakat within a year (Zaim, 2000). This section is defined as the right of the poor people in the Quran (51/19). In this respect, zakat is not rich people's mercy to poor people but is a right of poor people on rich people.

The important question that should be asked here is: How have poor people had such a right? A believer who believes in submission to Allah will answer this question as: "Because Allah says that 'And from their properties was given the right of the needy petitioner and the deprived"" (Quran: 51/19). However, the believer's submission to Allah is not an obstacle for him to attempt to understand why he has ordered people like that. Therefore, one should seriously think about how a poor person can have a right on the wealth of a rich person. It is certain that this intellectual quest will allow people to see better for whom economic opportunities came together. Nonetheless, the society cannot develop without people, capital owners, who use these opportunities well, however, these rich people should look back and help empty-handed people who are in despair. In response to the above question, it can be said as following.

\section{The Gainer and the Loser Are Not Independent of Each Other}

A rich person may not want to accept the thesis that poor people have a share in his wealth that he has gained by working. There may be people who acknowledge him to be right considering in terms of endeavor-gaining. However, this issue should be looked from a broader perspective. It is actually the society that provides an opportunity for a person to become rich. The capital owner uses the opportunities offered to him by society while buying or producing and selling. Large capitals are supplied by big and strong communities. The fact that one side of the society gradually deteriorates economically means that the section rising upwards cannot rise anymore since the weak ground will not lift the load that becomes heavier anymore. In this context, zakat is an important study to strengthen the collapsed sections of the society. It is necessary to remember the verses of "Allah will give increase for deeds of charity..." (Quran: 2/276). 


\section{It Is Hard to Say That the Economic System Operates in a Fair Way}

It is hard to say that all things are conducted in a fair way in the production and trade. The tendency of money under market conditions is mainly in the direction of big money sets. Through zakat, the wealth which is in circulation within the normal market rules can be redistributed by divine intervention. The purpose of the second distribution is to create balance by protecting the poor segment from the social and economic instability in the first distribution. This process does not completely eliminate the economic income differences but prevents the opening of a gap in the income inequality between two segments. The difference in income is reduced by a certain amount of corrections in the society's differences in economic income every year (Bulac, n.d., pp. 120-132).

The issue can be viewed in terms of wealthy individuals. A businessman working honestly cannot be sure whether unlawful profit is included in his wealth, no matter how much he pays attention. In this sense, zakat becomes an action that enhances the legitimacy of his wealth. Here, it is also necessary to remember the verses of "Of their goods, take alms, that so thou mightiest purify and sanctify them..." (Quran: 9/103).

\section{It Is a Requirement of the Humanity to Help Poor People}

Beyond economic concerns, the virtue of humanity requires to help a person who is about to die of hunger. Ignoring the weak and helpless groups that are stuck between power groups who are in constant dispute with each other is an irresponsibility that cannot be accepted by any human normally. Zakat will help people who are in need of emergency aid hold on to the life with a good organization.

Zakat is an institution which has been suggested for Muslims living in simpler conditions compared to the present day and which has been developed in time. However, whether it can be modernized is being discussed.

\section{Can Zakat Be Modernized?}

Some researchers have laid emphasis on whether zakat can be integrated into modern conditions. The main reason that required performing the study in this field is the fact that rich Muslims pay taxes as required by legal obligations and give zakat as required by religious obligations (Ozdemir, 2013). Researchers have looked for solutions to save them from these double obligations.

A partial solution to this issue has been found in Turkey as follows: The supports provided by those who help the institutions operating for the public interest are deducted from the tax to a certain extent. The legislative regulations regarding the foundations and associations working for the public interest (e.g. T. R. Income Tax Law, 1961, 89: 1/4) provide an opportunity for rich Muslims to consider their zakat as a tax.

In recent years, governments in many countries such as Malaysia, Indonesia, and Pakistan have established zakat collection institutions (Hudayati \& Tohirin, 2010; Ahmad, 2004). There is not any official institution that collects zakat in Turkey. This situation makes the benefit expected from zakat completely unachievable since money of zakat can be spent for improper purposes due to the legal gaps and inadequate supervision. It can be considered on allowing a powerful organization such as the Directorate of Religious Affairs to collect and distribute zakat. According to the Tug (1973), who worked as a dean for a period in Marmara University Faculty of Theology, the Directorate of Religious Affairs should be authorized to collect and distribute zakat (Tug, 1973). In this way, the money of zakat can be collected under the supervision of an institution and can be distributed from here to the real poor. 


\section{Can Zakat Be a Universal Model?}

Can people take some amount of rich person's property and transfer it to the poor person be a remedy to improve the income inequality between the rich and poor people a little bit and to improve the conditions of people who are under the poverty threshold? In order to give a positive answer to this question, some amount of the wealth of the rich person should be regarded as the legal right of the poor person. However, the realization of this depends on the fact that it is based on a universal philosophical basis. What can become these bases are shown below:

(1) People are not independent of the society in which they live. A producing person gains wealth not only on his own but also through the opportunities offered to him by the society. The society, at least, gives support to the manufacturer through consumption. Therefore, a wealthy person owes to the society.

(2) As it is explained above, it is necessary to make corrections in favor of the poor people at certain intervals in the free market economy.

(3) One of the state's duties is to satisfy minimum basic needs of the poor. This duty should not be left only to the merciful people or the ability of local governments. The fact that a person dies of hunger is a responsibility that concerns all people because communities are closer to each other and because of the globalization of trade relations.

(4) For a healthy and sustainable growth, it is compulsory to prevent inequality in income distribution from reaching extreme extents.

These and similar reasons which are stated briefly can provide universal philosophical bases required to convert zakat into a universal model. The establishment of these bases seems easier in Muslim communities compared to others due to the factor of faith. Spending a $2.5 \%$ share which is collected from the richest segment once a year for the poorest segment can be used as a tool to reduce poverty all around the world.

\section{Conclusion}

The inequality in income distribution at a large extent can be a big threat causing worldwide destruction. Poverty and desperation are a great danger not only for the poor people but also for all mankind. Islam has taken some measures to improve the income inequality. Zakat, alms-charity, sadaqah, sacrifices, and trust institutions are among these. The Quran says that poor people have a right on the wealth of rich Muslims and orders that $2.5 \%$ of their wealth should be taken once a year and distributed to the poor people. The main purpose of zakat which is compulsory for every rich Muslim is to get the consent of Allah as in other worships. There is not an official institution in charge of collecting zakat in most of the Islamic countries. Therefore, rich Muslims directly give their zakat to a poor person or a non-governmental establishment by calculating their zakat voluntarily. However, this does not provide the realization of the purpose of zakat. Otherwise, double cash outflows occur for Muslims, who pay both tax and zakat, and some Islamic countries are in search of a solution to this problem.

Zakat can be taken as a universal model in fighting against poverty. The state can collect a certain percentage of the goods of the rich people to give to the poor people. This portion taken from the goods of the rich is a legitimate right of the poor people. The fact that the economic system is more advantageous for the rich people makes the poor people poorer. The resulting problems are not only the problems of the poor people but also of all mankind. It may be useful to elaborate on the following issues to gain this awareness: 
- The gainer and the loser are not independent with each other.

- It is hard to say that the economic system operates in a fair way.

- It is a requirement of the humanity to help poor people.

- The problem of poverty is not only a concern of the poor people but also of all mankind.

\section{References}

Ahmad, H. (2004). The role of zakah and awqaf in poverty alleviation. Occasional Paper, 8. Jiddah, IRTT.

al-Mawsili, A. (1937). Al-Ikhtiyār li-ta'līl al-mukhtār, Beirut, Dāru kutub al-'ilmiyya.

Bulac, A. (n.d.). Zekat kurumunun manevi sosyal anlami. Türkiye'de zekat potansiyeli. Istanbul: ISAV.

Cagrici, M. (1988). Adalet. The Diyanet Islamic Encyclopedia, 1, 341-343.

Cruz, M., Foster, J., Quillin, B., \& Schellekens, P. (2015). Ending extreme poverty and sharing prosperity: Progress and policies,
prns
of World
Bank.
Retrieved
on
Feb.
02 ,
2016 from

http://www.worldbank.org/en/research/brief/policy-research-note-03-ending-extreme-poverty-and-sharing-prosperity-progres s-and-policies

Erkal, M. (2013). Zekat. The Diyanet Islamic Encyclopedia, 45, 187-207.

Eskicioglu, O. (1989). Modern vergi anlayişi ve zekat. DEÜIFD, 5, 225-250.

Hudayati, A., \& Tohirin, A. (2010). Management of Zakah: Centralized vs. Decentralized Approach, Seventh International Conference-The Tawhidi Epistemology: Zakat and Waqf Economy. Bangi., 351-374.

Islahi, A. (1993). Islamic distributive scheme: A concise statement. Journal of Objective Studies, 5(1), 98-111.

Ozdemir, A. (2013). Zekat ve vergi mükellefiyetinde firsat eşitliği ve adaletin sağlanmasi. EKEV Akademi Dergisi, 17(56), 1-10.

T. R. Income Tax Law. (1961). Retrieved from http://www.mevzuat.gov.tr/MevzuatMetin/1.4.193.pdf

Tug, S. (1973). Zekatin yeniden merkezileştirilmesi. Islam Medeniyeti, 3(28), 30-33.

Zaim, S. (2000). Resent interpretations of the economic aspects of zakah. In I. Imtiazi (Ed.), Management of zakah in modern Muslim society (pp. 101-120). Jiddah, IRTI. 